\title{
52. CONSOLIDATION CHARACTERISTICS OF JAPAN TRENCH SEDIMENTS
}

\author{
Les E. Shephard and William R. Bryant, Department of Oceanography, Texas A \& M University, \\ College Station, Texas
}

\section{INTRODUCTION}

Consolidation characteristics of marine sediments have been determined for several different geologic provinces (cf. Hamilton, 1959, 1964; Keller and Bennett, 1973; Trabant, 1977; and Shephard et al., 1978). These data have been used to enhance interpretation of sediment processes; to develop density, porosity, permeability, and depth relationships; to predict excess pore water pressures; as well as to determine the amount of sediment originally present before consolidation.

With the inception of plate tectonic theory several geologic and geotechnical investigations have been performed to aid in delineating those processes associated with fore-arc slope development in various trench systems (cf. Lee et al., 1973; Carson et al., 1974; Seely et al., 1974; Bouma and Moore, 1975; Trabant et al., 1975; Moore and Karig, 1976; and Seely, 1977). Many of these studies have included consolidation testing. Lee et al. (1973) tested overconsolidated sediments below 300 meters at DSDP Site 181 (Aleutian Trench). Trabant et al. (1975) reported highly overconsolidated sediments below 397 meters at DSDP Site 298 (Nankai Trough). Carson (1977) discussed overconsolidated mudstones dredged from the Cascadia Basin. Each of these studies suggests the state of overconsolidation results from tectonically induced stress, deformation, and uplift. The ensuing discussion will describe consolidation test results from samples obtained in the Japan Trench province during DSDP Legs 56 and 57.

\section{TECHNIQUES}

Ten consolidation tests were performed, using Anteus back pressure consolidometers, on samples obtained from DSDP Sites 436, 438, and 440 (see Table 1). General testing procedures and the primary advantages of the Anteus consolidometer can be found in Lowe et al. (1964) and Bowles (1970).

The state of consolidation was determined by comparing the preconsolidation pressure, $P_{c}$, calculated using Casagrande's technique (1936), with the effective overburden pressure, $P_{o}$, computed assuming hydrostatic conditions. Sediment is normally consolidated if the present effective overburden pressure is the greatest ever imposed; hence $P_{c}$ equals $P_{o}$. Sediment is overconsolidated if it has been consolidated under a pressure in excess of the present effective overburden. Thus a $P_{c}$ greater than $P_{o}$ would indicate overconsolidation. Sediment which has not fully consolidated under the present overburden pressure is underconsolidated. In this case $P_{c}$ is less than $P_{o}$.

\section{CONSOLIDATION CHARACTERISTICS}

\section{Site $\mathbf{4 3 6}$}

Site 436, located on the crest of the outer trench slope, constitutes the Pacific Plate reference site. One sample $(365.5 \mathrm{~m})$, a dark brown pelagic clay, was tested with the intention of using the results as a standard for pelagic sediment not affected by convergence. Consolidation test results (Figure 1), plotted as void ratio, $e$, versus the logarithm of pressure, $P$, show the sample is underconsolidated. Keller and Bennett (1973) and Trabant et al. (1975) found similar results for pelagic sediments tested below 200 meters sub-bottom. They attributed the state of underconsolidation to interparticle bonding and low permeability.

\section{Site 438 (Holes 438 and 438A)}

Site 438 was drilled in the outer margin of a broad terrace located on the upper continental slope. Three samples were tested from this site (Hole 438, $20.5 \mathrm{~m}$, and Hole 438A, $236 \mathrm{~m}$ and $364.5 \mathrm{~m}$ ) to determine the consolidation characteristics of sediment affected only by lithostatic pressures. The sample tested at 20.5 meters consisted of an olive gray silty clay, whereas the lower two samples were lithified dark olive gray silty clays. The results of the consolidation tests (Figures 1 and 2) show these samples are underconsolidated with the degree of underconsolidation increasing with depth.

\section{Site 440 (Holes 440, 440A, and 440B)}

Site 440 was drilled in a midslope terrace located on the landward wall of the Japan Trench. Six consolidation tests were performed on samples obtained at depths ranging from 4.4 meters to 593.7 meters sub-bottom (Figures 3-5). The samples consisted of dark to olive green silty clays, with the deeper samples $(400.5$ and $593.7 \mathrm{~m}$ ) being lithified and foliated. All of the samples tested were underconsolidated with the degree of underconsolidation increasing to a depth of $593 \mathrm{~m}$.

\section{DISCUSSION}

A sediment is underconsolidated if its pore water pressures are in excess of hydrostatic or steady state pressures. Thus any factor that impedes the flow of water through sediment or induces stress in such a way that excess pore water pressures develop contributes to underconsolidation. Some of these factors include (1) high sedimentation rates; (2) low permeabilities; (3) laterally applied stresses; and (4) physicochemical interparticle bonding and cementation. The state of under- 
TABLE 1

Consolidation Characteristics and Physical Property Data for DSDP Sites 436, 438, and 440

\begin{tabular}{|c|c|c|c|c|c|c|c|c|}
\hline Section & $\begin{array}{l}\text { Depth } \\
\text { Sub-bottom } \\
\text { (m) }\end{array}$ & $\begin{array}{c}\text { Effective } \\
\text { Overburden } \\
\text { Pressure } \\
P_{O}\left(\mathrm{~kg} / \mathrm{cm}^{2}\right)\end{array}$ & $\begin{array}{c}\text { Preconsolidation } \\
\text { Pressure } \\
P_{c}\left(\mathrm{~kg} / \mathrm{cm}^{2}\right)\end{array}$ & $\begin{array}{l}\text { Water } \\
\text { Content } \\
(\%)\end{array}$ & $\begin{array}{l}\text { Void } \\
\text { Ratio }\end{array}$ & $\begin{array}{c}\text { Porosity } \\
(\%)\end{array}$ & $\begin{array}{l}\text { Bulk } \\
\text { Density } \\
\left(\mathrm{g} / \mathrm{cm}^{3}\right)\end{array}$ & $\begin{array}{l}\text { Specific } \\
\text { Gravity }\end{array}$ \\
\hline $436-39-4$ & 365.5 & 17.75 & 1.25 & 53.50 & 1.53 & 60.48 & 1.73 & 2.85 \\
\hline $438-3-4$ & 20.5 & 1.30 & 0.495 & 75.70 & 1.99 & 67.21 & 1.56 & 2.70 \\
\hline $438 \mathrm{~A}-19-4$ & 236 & 11.85 & 3.00 & 126.45 & 3.11 & 75.66 & 1.36 & 2.46 \\
\hline $438 \mathrm{~A}-33$ & 364.5 & 16.15 & 2.30 & 93.11 & 2.25 & 69.21 & 1.46 & 2.44 \\
\hline $440-1-3$ & 4.40 & 0.24 & 0.16 & 65.46 & 1.74 & 63.55 & 1.60 & 2.66 \\
\hline $440-4-3$ & 31 & 1.67 & 0.54 & 71.09 & 1.93 & 65.82 & 1.59 & 2.71 \\
\hline $440 \mathrm{~A}-2-4$ & 87.5 & 4.70 & 1.50 & 80.85 & 2.09 & 67.68 & 1.53 & 2.60 \\
\hline $440 \mathrm{~A}-6-2$ & 123.5 & 6.76 & 0.230 & 67.51 & 1.75 & 67.51 & 1.59 & 2.60 \\
\hline $440 \mathrm{~B}-28-3$ & 400.5 & 23.06 & 1.00 & 74.13 & 1.78 & 64.09 & 1.53 & 2.44 \\
\hline $440 \mathrm{~B}-48-5$ & 593.7 & 34.43 & 0.91 & 66.97 & 1.64 & 62.06 & 1.56 & 2.46 \\
\hline
\end{tabular}

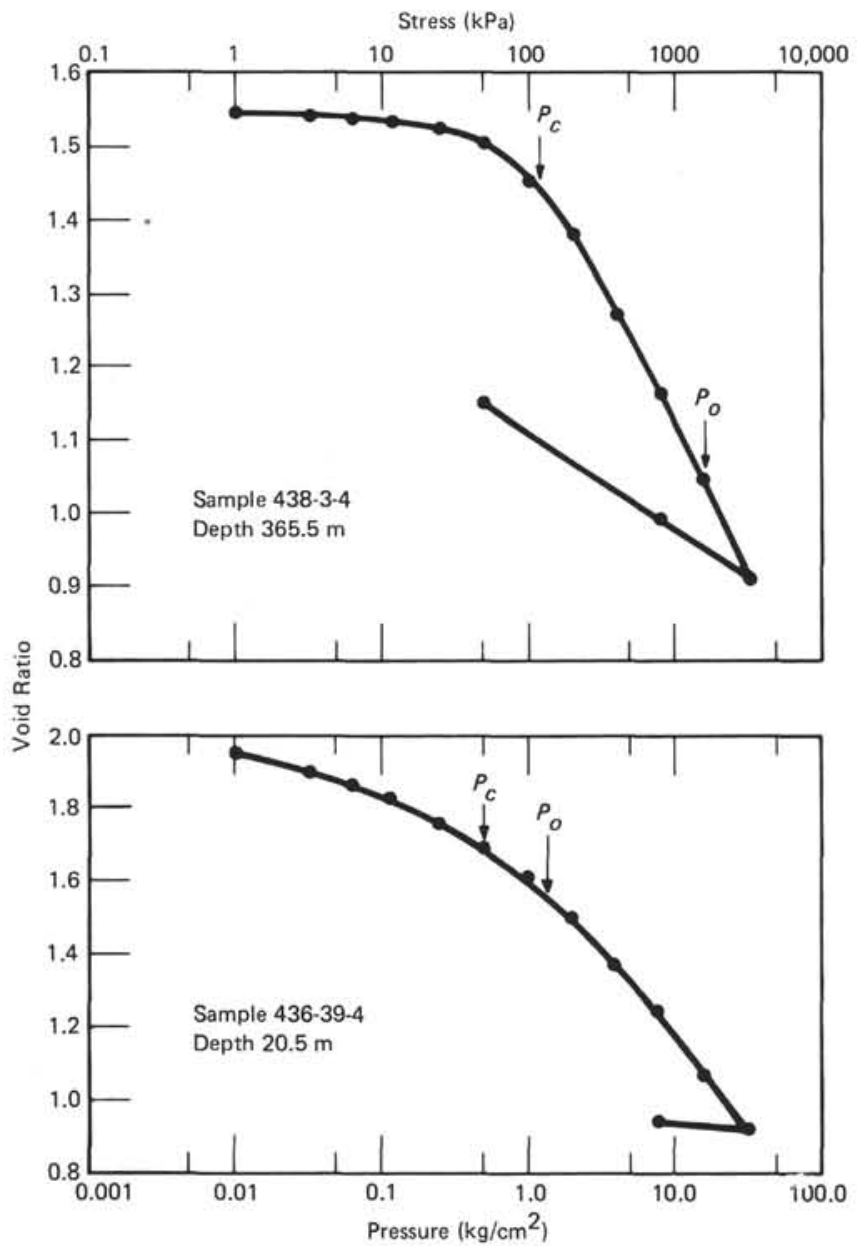

Figure 1. Void ratio versus logarithm of pressure (e-log P) curves for Site 436, 365.5 m, and Site 438, $20.5 \mathrm{~m}$.

consolidation displayed by Japan Trench sediments (Figure 6) is both atypical of lower slope sediments associated with convergent margins (Lee et al., 1973; Trabant et al., 1975; Carson, 1977) and difficult to explain by those factors which commonly result in underconsolidation.

Bredehoft and Hanshaw (1968) demonstrated theoretically that excess pore pressures may approach litho-

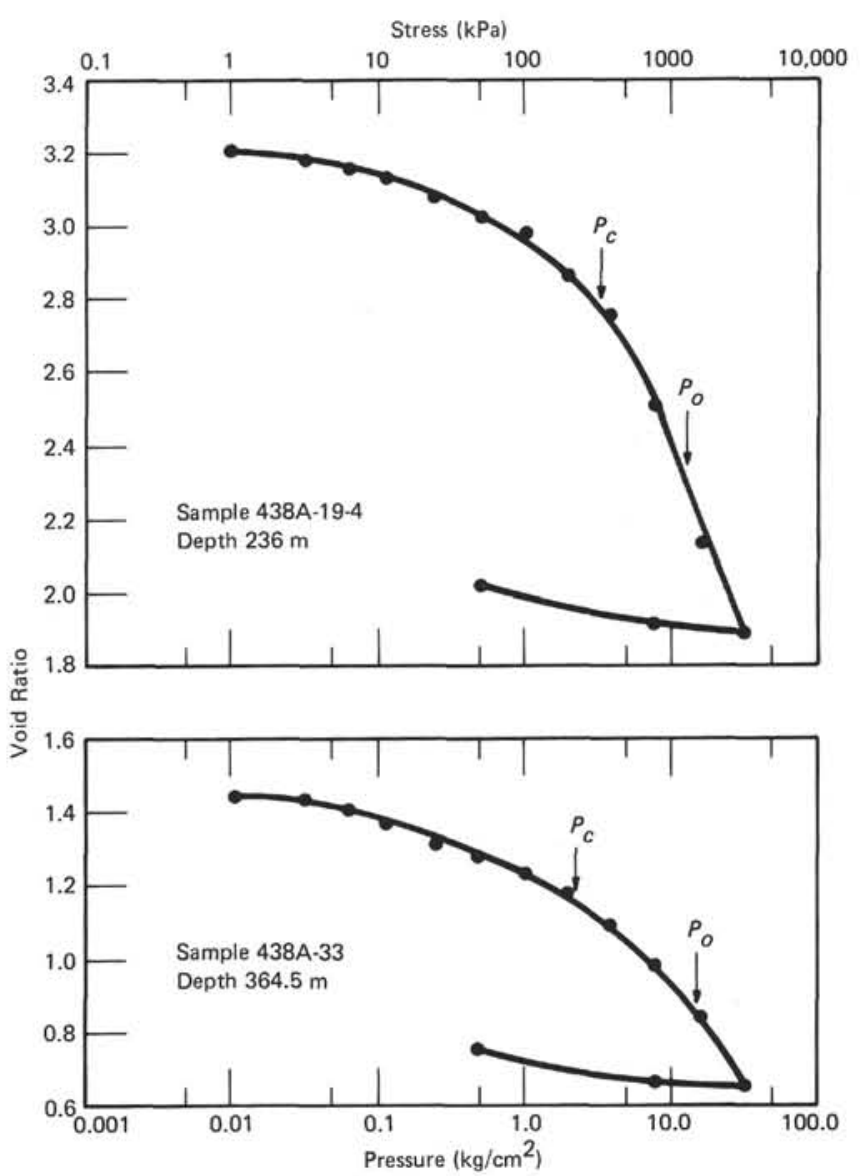

Figure 2. Void ratio versus logarithm of pressure (e-log P) curves for Site 438, $236 \mathrm{~m}$ and $364.5 \mathrm{~m}$.

static pressures in sediments accumulating at $500 \mathrm{~m} / \mathrm{my}$, assuming permeabilities of less than $1 \times 10^{-8} \mathrm{~cm} / \mathrm{s}$. They also stated that negligible excess pore pressures would develop in sediments with permeabilities of $10^{-6}$ $\mathrm{cm} / \mathrm{s}$ or higher. Sediment accumulation rates for Site 440 vary from approximately $100 \mathrm{~m} / \mathrm{my}$ to $230 \mathrm{~m} / \mathrm{my}$, whereas permeabilities range from $10^{-6} \mathrm{~cm} / \mathrm{s}$ to $10^{-7}$ $\mathrm{cm} / \mathrm{s}$, depending on porosity (Figure 7). Thus neither sedimentation rates nor permeabilities appear to be of sufficient magnitude to result in the excess pore pres- 


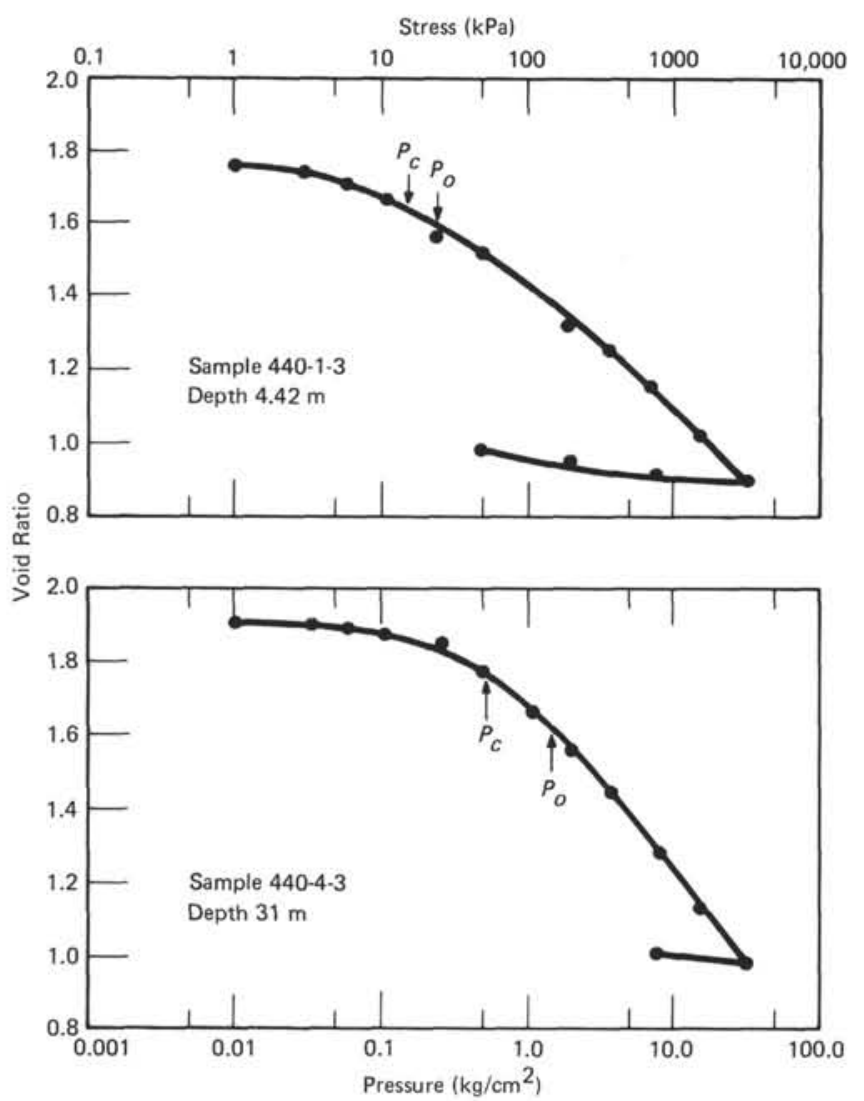

Figure 3. Void ratio versus logarithm of pressure (e-log P) curves for Site 440, $4.4 \mathrm{~m}$ and $31.0 \mathrm{~m}$.

sures and high degree of underconsolidation displayed by these sediments.

Excess pore pressures resulting from tectonic stress approach lithostatic pressures in Gulf of Alaska sediments (Hottman et al., 1978). However, Japan Trench sediments appear to have adequate permeabilities to allow dissipation of any excess pore pressures developed in this manner over the past few million years. Dissipation of tectonically induced excess pore pressures would result in overconsolidation rather than in the highly underconsolidated state present.

Two other factors which warrant mention when discussing underconsolidation of Site 440 sediments are sample disturbance and the consolidation characteristics of diatomaceous sediments. Prior to testing, examination of each consolidation sample, visually and by $\mathrm{x}$-radiography, revealed minimal disturbance. The general character of the $e$-log $P$ curves also suggests minimal sample disturbance.

Since samples tested from Site 440 contain up to 35 per cent diatoms, they may be considered diatomaceous mudstones and oozes. Diatomaceous oozes display unique geotechnical properties: high void ratios, porosities, and water contents and low bulk densities and compressibilities (Silva, 1974; and Hamilton, 1976). The particle-toparticle interaction between diatoms and clays may result in a rigid framework of diatom tests having low compressibility very similar to diatomaceous oozes. In

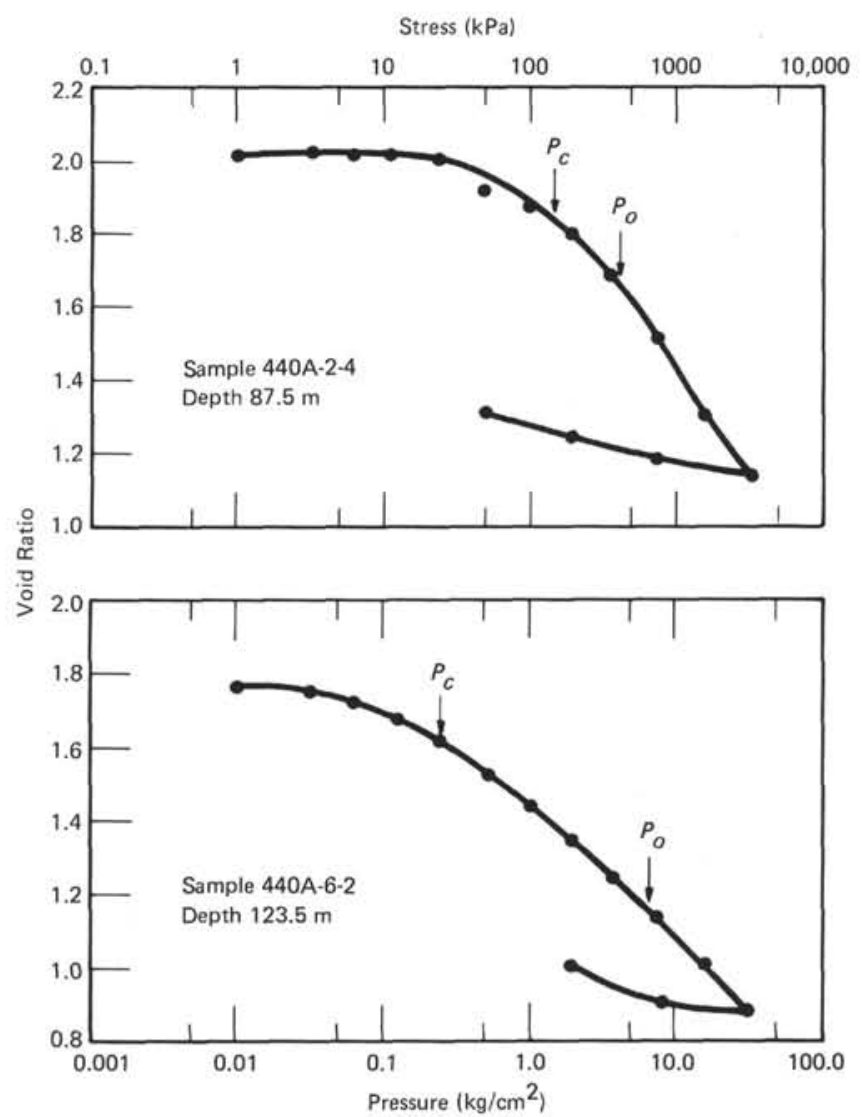

Figure 4. Void ratio versus logarithm of pressure (e-log P) curves for Site 440, $87.5 \mathrm{~m}$ and $123.5 \mathrm{~m}$.

$s i t u$, this diatom clay framework appears able to withstand the stresses imparted slowly by lithostatic and tectonic forces, but when "rapidly" loaded, as in a laboratory consolidation test, this structure appears to collapse readily.

Japan Trench inner slope sediments have unique consolidation characteristics compared to sediments from other convergent margins. These characteristics are difficult to explain using only those factors conventionally employed when discussing underconsolidated sediments. The unique geotechnical behavior of diatomaceous oozes, however, may indicate that the abundance of diatoms in these sediments is one significant factor contributing to the state of underconsolidation.

\section{REFERENCES}

Bouma, A. H., and Moore, J. C., 1975. Physical properties of deep-sea sediments from the Philippine Sea and Sea of Japan. In Karig, D. E., Ingle, J. C., Jr., et al., Init. Repts. $D S D P$, 31: Washington (U.S. Govt. Printing Office), 535-568.

Bowles, J. E., 1970. Engineering Properties of Soils and Their Measurement: New York (McGraw-Hill).

Bredehoft, J. D., and Hanshaw, B. B., 1968. On the maintenance of anomalous fluid pressures: Thick sedimentary sequences. Geol. Soc. Am. Bull., 81, 1097-1106.

Carson, B., 1977. Tectonically induced deformation of deepsea sediments off Washington and Northern Oregon: Mechanical consolidation. Mar. Geol., 24, 289-307. 


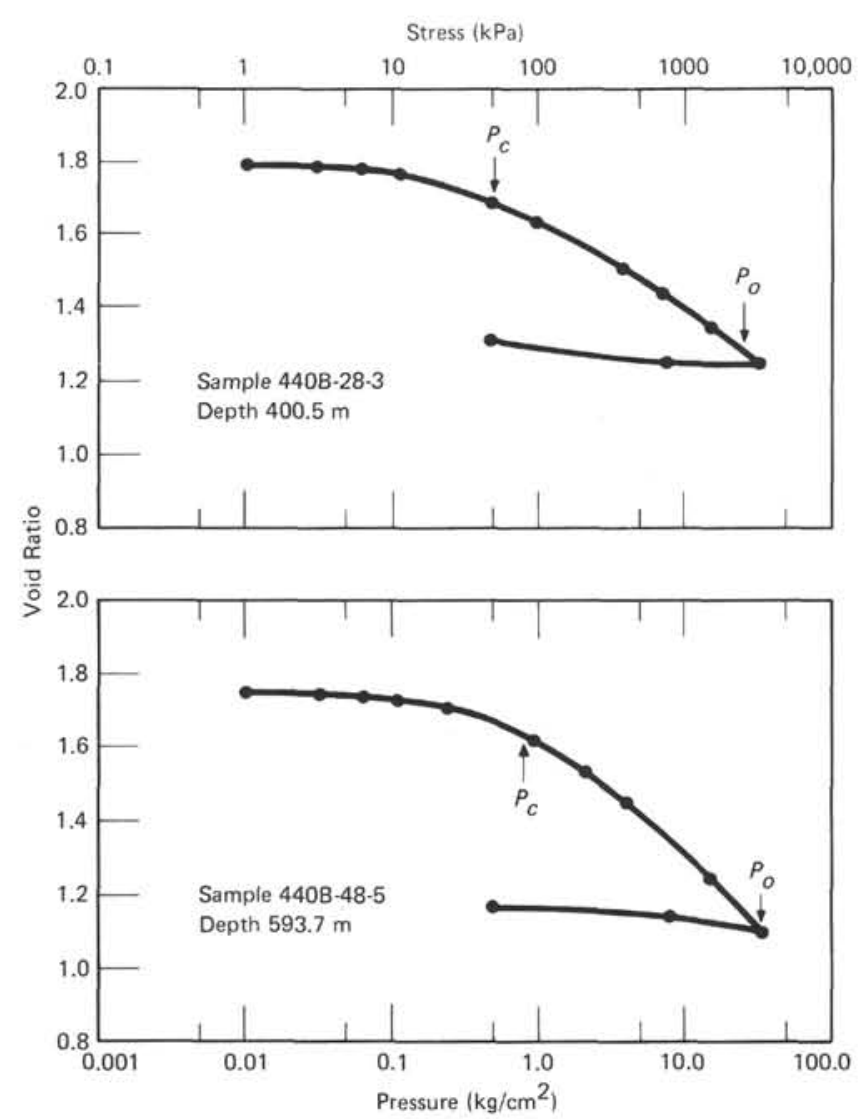

Figure 5. Void ratio versus logarithm of pressure (e$\log$ P) curves for Site 440, $87.5 \mathrm{~m}$ and $123.5 \mathrm{~m}$.

Carson, B., Yuan, J. W., Myers, P. B., Jr., and Barnard, W. D., 1974. Initial deep-sea sediment deformation at the base of the Washington continental slope: A response to subduction. Geology, 2(11), 561-564.

Casagrande, A., 1936. The determination of the pre-consolidation load. Proc. Int. Conf. Soil Mech. Found. Eng. (Cambridge), v. 3.

Hamilton, E. L., 1959. Thickness and consolidation of deepsea sediments. Geol. Soc. Am. Bull., 70, 1399-1424.

1964. Consolidation characteristics and related properties of sediments from experimental Mohole (Guadalupe site). J. Geophys. Res., 69, 4257-4269.

1976. Variations in density and porosity with depth in deep-sea sediments. J. Sediment Petrol., 26, 280-300.

Hottman, C. E., Smith, H. E., and Purcell, W. R., 1978. Relationship among earth stresses, pore pressure and drilling problems, offshore Gulf of Alaska [paper presented at the fifty-third Annual Fall Technical Conference, Society of Petroleum Engineers, Houston], Paper 7501.

Keller, G. H., and Bennett, R. H., 1973. Sediment mass physical properties-Panama Basin and Northeastern Equatorial Pacific. In van Andel, T. H., Heath, G. R., et al., Init. Repts. DSDP, 16: Washington (U.S. Govt. Printing Office), 499-512.

Lee, H. J., Olsen, H. W., and von Huene, R., 1973. Physical properties of deformed sediments from Site 181. In Kulm, L. D., von Huene, R., et al., Init. Repts. DSDP, 18: Washington (U.S. Govt. Printing Office), 701-719.

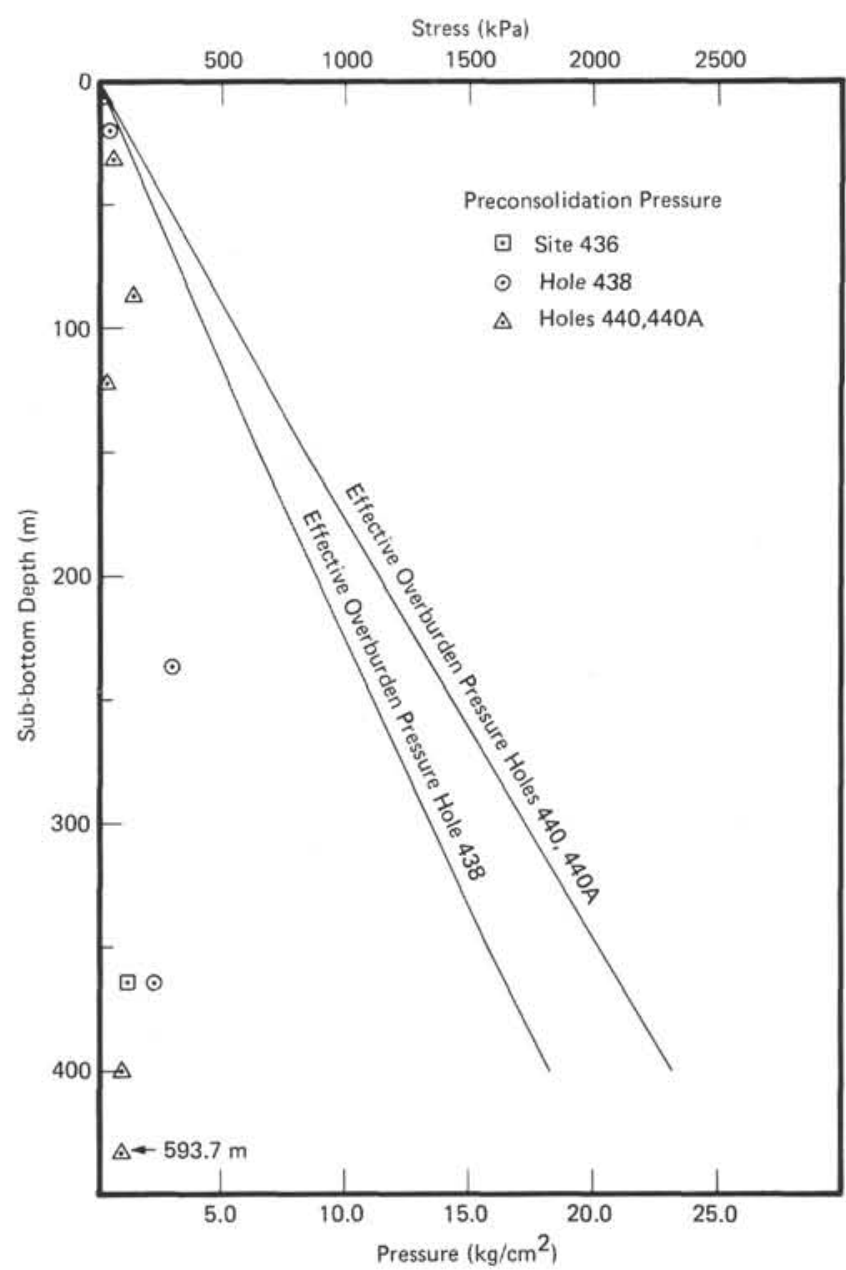

Figure 6. Preconsolidation pressures, $\mathrm{P}_{\mathrm{c}}$, and effective overburden pressures, $\mathrm{P}_{\mathrm{o}}$, versus depth for all samples tested. Note increasing difference between $\mathrm{P}_{\mathrm{c}}$ and $\mathrm{P}_{\mathrm{o}}$ with increasing depth.

Lowe, J., III, Zaccheo, P. F., and Feldman, H. S., 1964. Consolidation testing with back pressure. J. Soil Mech. Found. Div., Am. Soc. Civ. Eng., 90, 69-86.

Moore, J. C., and Karig, D. E., 1976. Sedimentology, structural geology and tectonics of the Shikoku subduction zone, southwestern Japan. Geol. Soc. Am. Bull., 87, 1259-1268.

Seely, D. R., 1977. The significance of landward vergence and oblique structural trends on trench inner slopes. In Talwani, M., and Pitman, W. C., III (Eds.), Island Arcs, Deep Sea Trenches and Back-Arc Basins: Washington (American Geophysical Union), pp. 187-198.

Seely, D. R., Vail, P. R., and Walton, G. C., 1974. Trench slope model. In Burk, C. A., and Drake, C. L. (Eds.), The Geology of Continental Margins: New York (Springer-Verlag), pp. 249-260.

Shephard, L. E., Bryant, W. R., and Dunlap, W. A., 1978. Consolidation characteristics and excess pore pressures of Mississippi delta sediments. Offshore Technology Conference, Houston, Paper 3167, pp. 1037-1048.

Silva, A. J., 1974. Marine geomechanics: Overview and projections. In Inderbitzen, A. L. (Ed.), Deep Sea Sediments: New York (Plenum Press), pp. 45-76. 


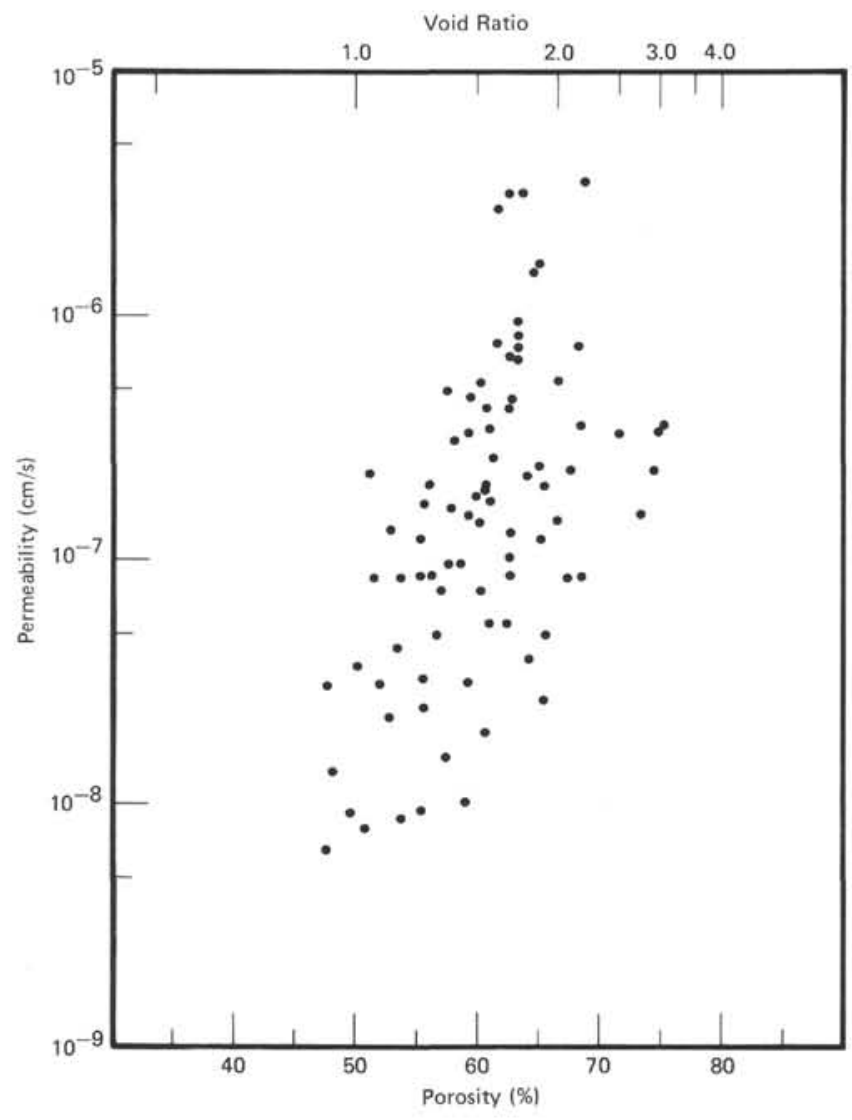

Figure 7. Permeability-porosity plot of all samples tested.

Trabant, P. K., 1977. Synthesis of physical properties data from Leg 41 of the Deep Sea Drilling Project. In Lancelot, Y., Seibold, E., et al., Init. Repts. DSDP, 31: Washington (U.S. Govt. Printing Office), 1199-1213.
Trabant, P. K., Bryant, W. R., and Bouma, A. H., 1975. Consolidation characteristics of sediments from Leg 31 of the Deep Sea Drilling Project. In Karig, D. E., Ingle, J. C., Jr., et al., Init. Repts. DSDP, 31: Washington (U.S. Govt. Printing Office), 569-572. 